\begin{tabular}{c} 
Volume and Issues Obtainable at Center for Sustainability Research and Consultancy \\
Journal of Business and Social Review in Emerging Economies \\
ISSN: 2519-089X (E): 2519-0326 \\
Volume 6: No. 1, March 2020 \\
CSRᄃ \\
Journal homepage: www.publishing.globalcsrc.org/jbsee \\
\hline
\end{tabular}

\title{
Impact of Macroeconomic Conditions, Industry Attributes and Firms Related Variables on Capital Structure: A Cross Industry Analysis
}

\author{
${ }^{1}$ Rana Shahid Imdad Akash, ${ }^{2}$ Muhammad Mudasar Ghafoor, ${ }^{3}$ Nida Saddique \\ ${ }^{1}$ Assistant Professor, School of Business Management, NFC-IEFR, Faisalabad, Pakistan. \\ shahid.imdad@yahoo.com \\ ${ }^{2}$ Assistant Professor, University of the Punjab, Jhelum Campus, Jhelum. Pakistan. \\ mudasar@pugc.edu.pk.com \\ ${ }^{3}$ Institute of Business Management, University of Agriculture, Faisalabad, Pakistan. \\ nida_sidique201@yahoo.com
}

\begin{tabular}{l}
\multicolumn{1}{c}{ ARTICLE DETAILS } \\
\hline History \\
Revised format: February 2020 \\
Available Online: March 2020 \\
Keywords \\
Seemingly unrelated \\
regression, leverage, financial \\
market.
\end{tabular}

JEL Classification:

B22, L79, O49

\begin{abstract}
Purpose: This study is conducted to examine the main strength of firms' specific variables, industry effects and macroeconomic conditions in predicting the capital structure choices of non financial listed companies of Pakistan Stock Exchange (PSX-100). Design/Methodology/Approach: To perform the study, a sample of twelve sectors covering a period from 2012 to 2017 is taken from PSX-100. Seemingly Unrelated Regression (SUR) model is applied to explore the capital structure choices. Results of study indicate that the short term debt plays a major part in designing the capital structure of listed companies of PSX-100.

Findings: Macroeconomic conditions have been identified to cause an increase in financial distress and costs of debt unanimously. The financial distress and costs are significant in financial market developments for a time horizons.

Implications/Originality/Value: The development in financial markets can have an opportunity to increase the choice of capital structure of firms optimistically. It is explored that source of capital choice seems to decrease in agency behavior and risk due to refinancing. The less agency problem and less risk provide better choice of debt and future growth to the financial market. The growth environment is life blood of financial market and economy.
\end{abstract}

(C) 2020 The authors, under a Creative Commons AttributionNonCommercial 4.0

Corresponding author's email address: shahid.imdad@ yahoo.com

Recommended citation: Akash, R.S.I., Ghafoor,M.M., \& Siddique,N. (2020). Impact of Macroeconomic Conditions, Industry Attributes and Firms Related Variables on Capital Structure: A Cross Industry Analysis. Journal of Business and Social Review in Emerging Economies, 6(1), 287-300

DOI: $10.26710 /$ jbsee.v6i1.1058 


\section{Introduction}

The process of creation of value is the main study of Economics and Finance. The dynamics of capital structure studies intended to visualize and computation of aggregate firm value. The value creation process is the core area for best asset utilization and to ultimate increase the productivity and growth in this domain. It has gained a lot of popularity in the corporate financial economics in present era. Capital structure has been studied extensively for more than 60 years in industrialized economies. Capital structure remained a continuous study area by the researchers, academicians, and practioners. The long debate on the choice of capital structure is as old as the concept of finance. Finance is the life blood of every corporation for every corporation needs financing either from internal or external sources to manage its operations effectively.

The most common MM theorem of Modigliani and Miller (1958) has raised the issue of nexus between value at market and firm's capital structure choices from last six decades. The MM theorem (1958) elaborate that firm value has the independent behavior with it. The finacing decisions which mean that the debt and equity finances has no impact on firm value. It is called irrelevant theorem because firm value is not influenced to choice of capital structure. Among capital structure theories i.e. static trade-off, theory, market timing theory, free cash flow theory, pecking order theory, agency theory and signaling theory a part from these theories provide supporting evidence and some studies exhibit nexus between value at market and firm's capital structure. Zweibel (1996) has identified that managers are the best users of capital structure choices and they enhance their trading activities according to the benefits of capital structure choices which has nexus not only with firms related variables but also with macroeconomic conditions and cross country effect, which has been proved through cross country analysis in the past and current era in African context, which is an underdeveloped economy. Modigliani and Miller (1963) identified that there may be tradeoff (between cost and benefits of debt and equity. Yet it observed that managers always operate choices according to benefits of their firm value because they are best protector of the firm value. Pakistani market is an underdeveloped market; managers operating in it are behaving to protect profits after balancing costs and benefits.

The capital structure choices may change due to influence of macroeconomic factors in the market. The presence of such unpredictable factors in the market influences the capital structure of firms and can affect their value in the long run. The economies which are inefficient, imperfect, information asymmetric markets with different financing patterns like Pakistan where the investors can enhance their trading activities by noise trading. Eldomiaty (2007) has studied that emerging, underdeveloped, imperfect; information asymmetric with different financing patterns are optimized in particular. Levine (2004) has studied that through credit channel, nexus between macroeconomic conditions and the choice of capital structure can be evaluated. The condition of the market and intuitional factors are not the same between economies.

In the case of Pakistan where the market is not only imperfect and also transitional economy, it can be supported for the better understanding of risk and puzzle capital structure and investment decisions. It is most significant to the literature of capital structure policy and its risk. The capital structure decisions have important implications to investor behavior and economic activity at firm and financial market.

Several studies have been conducted in developed economies and emerging economies including Africa but in Pakistani context which is also a developing, imperfect, information asymmetric economy with different financing patterns, the study will be on cross industry. However no evidence was found, on the direct nexus between the macroeconomic conditions, firms related variables and capital structure choices of the firms collectively. 
In past studies, the existing literature also supports to this study in the context of Pakistan such as developing market. Second, it is an attempt in which the use of SUR model to resolve the issue of multicollinearity, endogeneity, thus it will provide an increase in the estimation power of the parameters. This study is an attempt to fill the gap in relation with existing literature to investigate the direct nexus between firms' related variables, industry attributes, macroeconomic conditions and capital structure of firms for the specific period of 2012 to 2017. The objective of this study is to explore the impact of macroeconomic conditions, industry attributes and capital structure decisions in companies of Pakistan. The first part of the study consists of brief introduction of the study, second part covers the review of literature; a theory of capital structure and third part covers methodology. The fourth segment covers results and discussion and last segment elaborate the conclusion.

\section{Literature Review}

Many studies have been carried out on capital structure decisions of the firms but the research conducted by Modigliani and Miller (1958) has become a subject of debate in the field of research on capital structure choices. Modigliani and Miller (1958)'s theory which is known as the irrelevance theory explained that in a market in which everyone has perfect information about the market situation, no one can be charged the cost of tax, cost of transaction, cost of bankruptcy and denied access to trade assets. From past to now, some of the theories support the present study and others do not, but no one theory offered a proper definition of capital structure.

Myers (2001) investigated that all theories explained regarding capital structure decisions of firms work under certain conditions. Modigliani and Miller (1963) explained that the static trade off theory which originated from Modigliani and Miller (1958) theory found that cost of debt was irrelevant to tax. Corporations can get tax advantage when they set higher target of debt Myers (1984) elaborated the static trade of which a firm selects as a target of debt and equity to keep cost and benefits in view. This may cause agency problems and financial distress when there is no trade off between cost and benefits. Static trade of theory can be subdivided into two set of theories namely tax and bankruptcy theory, secondly information asymmetry and signaling theory.

Kim (1978), Kraus and Litzenberger (1973), Miller (1977) and Modigliani and Miller (1963) investigated that firms always try to set target capital structure in which they can create balance between the benefit of debts and cost on debts.

Signaling theory on the other side explained that information asymmetric may create problem in between the internal as well as external stakeholders of the firms. Pecking order theory is the base of information asymmetric theory in which the firms have to make the orders while choosing the choices (Myers, 1984; 2001; Myers and Majluf, 1984). Graham and Harvey (2001) argued that firms always rely on capital structure choices by generating signals for market's potential investors.

Baker and Wurgler (2002) investigated that the market timing theory in relation with information asymmetric theory explained that firms involve in raising funds in accordance with favorable market situations. Kim and Berger (2008), Toy et al. (1974) tested the relationship of micro characteristics of firms. They found that growth rate and profitability have an influence on capital structure choices. As the sale and profitability increases the source of internal capital increase which may change the ratio of debt equity.

Barclay et al. (1995) elucidated that due to signaling effect the firms earning increase and market to book value of firms capital structure can be optimized. Tse and Jia (2007) explained that capital structure is not used for financial signaling and inside ownership with more or less or equal are likely to the signal. Durand (1952) claimed that the capital structure is irrelevant under perfect market and the firm value at 
market. Harris and Raviv (1990) tested the static and dynamic theory to recognize the main role of debt concerning investment for investors.

The valuable information is used to monitor management with efficient implementation through the effective operations of the firm.

Afza and Hussain (2011) recognized the factors of capital structure. It is found that the sectors of cable and electrical goods, automobile, and have significant influence on debt financing decisions. Titman and Wessels (1988) investigated that capital structure is negatively affected by profitability and smaller firms follow more the short term financing pattern. Antoniou et al. (2008) examined that not only firms' related variables have influence on capital structure choices but also uncontrollable factors prevail in economy. Banjeree et al. (2004) investigated that uncontrollable factors prevailing in economy can change the speed of adjustment of capital structure choices of firms.

Harkbarth et al. (2006) contributed that size of the capital of firms can be determined by capital structure choices. Henderson et al. (2006) explored that interest rate affects negatively debt choices of firms and it may change at different level from short to long term debt preferences. The evidences clarify the fact that macroeconomic variables impact and its direction with capital structure is not clear due to imperfect market, information asymmetric and are different pattern of financing in the market where the investors can enhance their trading activities to maximize the profit margin by noise trading which may relate to particular situation existing in the market.

The markets which are not perfect lead towards high demand which may cause an increase in industrial production, increase in gross domestic product (GDP), increase in exports, increase in market capitalization, increase in exchange rate, more inflation rate. More companies are willing to get debt at high rate of interest due to high profit margin prevail in the market.

\section{Theories of Capital Structure:}

The phenomenon of capital structure originated with the choice of capital structure of the firm where managers are held responsible for the choice. The mix of capital structure - where debt may provide signals in market. The managers are very confident regarding service of debt in the form of interest and debt payable installments. So, it may create more trust of investors and market value. It also provides the favorable signals of the firm size and net positive cash flows in future. It has also been provided the disagreement that more profitable firms have no need of more debt. The debt may lead to weak signals for investors in future prospects. The equity provides poor signal for investors in future prospects due overvalue and going to issue. This should produce negative signal in the market. The investors should show lack of interest which ultimately results in the turn down to the market value of the firm with higher level of risk.

\subsection{STATIC TRADE OFF THEORY (POT)}

Myers (1984) examined that the cost and benefit are related with the debt equity choice. The taxes provision, agency cost and financial distress cost based on the selection criteria of capital structure. The increase or decrease in share prices may be due to doubts in the situation of best choice to mix of capital structure. MM theorem of Modigliani and Miller (1958) provides evidence to support a perfect market theory. The corporate tax has effect on the theorem created by Modigliani and Miller (1963). TOT explained the optimal mix of capital structure. It also supported the maximization value with the present value of debt tax shield. 


\subsection{PECKING ORDER THEORY (TOT)}

Myers and Majluf (1984) argued that about POT, firms follow the order of capital structure. There are three sources of capital i.e. internal funds (Retained earnings), external funds (Bank loan) and equity. At first, the preference will be given to finance by firms through utilization of internal fund (Retained earrings), then external financing (Debt or bank loan) and finally, last resort public debt (Equity). Generally, firms are reluctant to financing by equity because of information asymmetry among managers and investors. The asymmetry of information may sustain risk and endanger the market value of the firm.

\subsection{SIGNALING AND INFORMATION ASYMMETRY THEORY}

Ross (1977) employed a financial signal and asymmetry of information approach of capital structure. The information quality of the firm to market is the life blood of a capital structure decisions. This may be based on selection of capital structure alternatives. The decisions of capital structure are evidence that information of company does not spread equally to both managers and investors. The managers are assumed to have better information compared to investors. The distribution of high quality information about capital structure maintained a lesser risk to value. The distribution of low quality information on capital structure maintained a higher risk to value. The distribution of information on capital structure at higher quality sustained positive signals and lower asymmetry of information. The distribution of information on capital structure at lower quality sustained signals and higher asymmetry of information.

\subsection{AGENCY COST THEORY (ACT)}

The behavior of manager and investor is very important while making the decisions on capital structure. ACT depends on the psychology of managers and this may not always work in the interest of owners. In accordance to capital structure choice with reference to POT, risk may not be aligned properly. The misalignment due to difference in hierarchy may lead to risk in returns to the owners. The equity is issued when it is overvalued and bought back when undervalue. Jensen and Meckling (1976) explained the agency problem in terms of monitoring the expenditure of the owners, bonding expenditures by the managers and minimizing residual volatility or risk. Swanson et al. (2003) described the details of agency issue to create and structure the cost of contracts, bonding, monitoring cost and opportunities of residual risk.

\subsection{TRANSACTION COST ECONOMICS (TCE)}

Williamson (1988) develope theoretical grounds of TCE. This particular approach is concerned with governance structure of a contractual association between two parties. The decisions regarding investment are based on the level of specificity of available assets of the firm. Higher the level of asset specificity is, more the firm will select equity as a tool of financing capital structure. The available assets having low value cannot be utilized properly and reemployed easily at the liquidation stage. The level of asset specificity at general basis, firm will select to debt as a tool of financing as a capital structure. Available assets having greater value can be utilized properly and reemployed easily at the liquidation stage. Coase (1937) considered TCE at difference perspective where a market to buy and to make based on a decision to utilize markets. Kochhar (1996) documented the debt capacity which is concerned to buy and equity capacity which is concerned to make.

\subsection{LIFE STAGE THEORY (LST)}

Frielinghaus et al. (2005) explained the life stages of an organization. The organizations live in organisms of similar fashion. The life cycle of an organization starts with birth and ends with death. At the level of maturity stage, the firm can utilize more debt. Bender and Ward (1993) proved that the life stages are being used to adjust the level of risk of a business. The risk adjustment of the business may decrease with the passage of time. The level of financial risk may increase with the passage of time. Adizes (1979) described that the life stage of a firm is utilized to explain the pattern of behavior on typical basis. 


\subsection{MARKET TIMING THEORY (MTT):}

Baker and Wurgler (2002) described that the capital structure has positive and strong relation to market timing. The timing of equity of previous attempts considered cumulative outcomes by capital structure. The new stocks issued are traded when overvalued and bought back when undervalued. Frank and Goyal (2004) claimed that there is no empirical support to prove the validity of MTT. It has no ability to explain the level of optimal mix of capital structure.

\section{Methodology}

To determine the relationship between micro characteristics of firms such as asset tangibility (AT), profitability $(\mathrm{P})$, size $(\mathrm{S})$, earning volatility (EV), growth opportunity (GO), tax shield (TS), dividend payout (DP) and proxies of capital structure such as short term leverage (STL), long term leverage (LTL) and total leverage (TL) of 12 non financial sectors - namely Textile (T), Food (F), Chemical \& Pharmaceutical (CP), Other Non Metallic Minerals (ONMM), Other Manufacturing (OM), Motor Vehicle \& Auto Parts (MVAP), Information, Communication \& Transport (ICT), Fuel \& Energy (FE), Paper Board (PB), Coke \& Refined Petroleum (CRP), Electric Machinery (EM) and Other Services (OS) which consist of 397 companies operating in Pakistan. Overall average has been used to investigate the relationship and by taking data from balance sheet analysis of PSX-100 for the period 2012 to 2017.

Data on macroeconomic variables such as GDP, imports (M), exports (X), inflation rate (INF), market capitalization (MC), exchange rate (ER) and interest rate (IR) have been collected from the World Bank website covering the period 2012 to 2017. To examine the level of different factors on capital structure choices, the following econometric models are used. To determine the effects of micro characteristics of firms on capital structure of the firms, the basic model is expressed as follows.

$$
L_{(i t)}=\alpha_{0}+\mathcal{X}_{i t}^{f c} \beta+\varepsilon_{(i t)}
$$

$L_{(i t)}$ is the dependent variable, a proxy of capital structure. $\beta$ represents the coefficient of firms characteristics, $\mathcal{X}_{(i t)}^{f c}$ is the vector of firms characteristics, while $\varepsilon_{(i t)}$ stands for disturbance term. The capital structure choices have effects on the industry. To capture these effects on the industry dummy variables "Dummy $y_{i}^{k "}$ are introduced in the basic model. The resulting model is presented as follows.

$$
L_{(i t)}=\alpha_{0}+X_{(i t)}^{f c} \beta+\sum_{k} \beta \text { Dummy }_{i}^{k}+\varepsilon_{(i t)}
$$

Dummy $y_{i}^{k}$ is a dummy variable for each industry. $\beta$ denotes the coefficient of each industry.

The model in equation (3) is used to evaluate further the effects of macroeconomic variables on capital structure. The model can be rewritten as follows.

$$
L_{(i t)}=\alpha_{0}+X_{(i t)}^{f c} \beta+\sum_{k} \beta D_{\text {Dummy }}^{k}+\chi_{(i t)}^{m} \beta+\varepsilon_{(i t)}
$$

$\chi_{(i t)}^{m}$ is a vector of macroeconomic variables. $\beta$ Denotes the coefficients of macroeconomic variables. In a given set of panel data where the number of cross $d=$ sections denoted by " $M$ " and number of time period "T". However to control unabsorbed heterogeneity the SUR model is used and it has been applied when there are two or more equations for same cross sections. SUR model is a way of estimating panel model "T" but not vide but not "n". SUR model has a property of contemporaneous correlation assumption. This model is appropriate in analyzing the same industry but different factors and this model handles various problems of the data as well. Parson and Titman (2007) have identified endogeneity and multicollinearity as main issues complicating the investigation of the relationship between different factors of capital structure choices. In this study, SUR is used to mitigate these problems because it is more powerful and robust econometric estimation technique to overcoming endogeneity and multicollinearity difficulties (Gujarati, 2003). 


\section{Results and Discussion}

Table-I indicates results of year wise mean comparisons of micro characteristics of firms and capital structure across the sectors. The minimum mean values were $0.553,0.140,0.365$ and maximum mean values were $0.605,0.240$ and 0.457 for STL, LTL and TL, respectively during the period 2012 to 2017. All the three leverage ratios were varying over the sample period. Based on the pattern of the data TL had the major chunk of the short term debt. STL was reduced from 0.457 to 0.365 . This ratio might decrease due to increasing interest rate. P, S, EV, GO, DP, AT, and TS had been changing over time in accordance with LTL and slightly with TL

Table I

Year Wise Mean Comparisons of Firms Specific Variables and Capital Structure across Sectors

\begin{tabular}{|c|c|c|c|c|c|c|c|c|c|c|}
\hline Years & S & EV & P. & GO. & AT & DP & TS & TL & LTL & STL \\
\hline 2012 & 0.644 & 0.105 & 0.056 & 0.482 & 0.444 & 0.031 & 0.644 & 0.553 & 0.140 & 0.413 \\
\hline 2013 & -0.026 & 0.071 & 0.132 & 0.469 & 0.387 & 0.030 & -0.026 & 0.602 & 0.145 & 0.457 \\
\hline 2014 & -0.187 & 0.061 & 0.043 & 0.590 & 0.869 & 0.031 & -0.187 & 0.605 & 0.240 & 0.365 \\
\hline 2015 & -0.168 & 0.066 & 0.146 & 0.587 & 0.783 & 0.030 & -0.168 & 0.591 & 0.212 & 0.379 \\
\hline 2016 & 0.198 & 0.053 & 0.119 & 0.560 & 0.340 & 0.033 & 0.198 & 0.595 & 0.199 & 0.396 \\
\hline 2017 & -0.551 & 0.059 & -0.067 & 0.533 & -57.920 & 0.155 & -0.551 & 0.593 & 0.185 & 0.408 \\
\hline
\end{tabular}

The table II indicates the description of variables and proxies for further analysis of macroeconomic, industry specific, firm related variables and capital structure across sectors of listed companies of Pakistan Stock Exchange (PSX-100)

Table II

Description of Variables and Proxies

\begin{tabular}{|l|l|}
\hline Variables & Proxies for the Calculation of Values of Variables \\
\hline Firm Size (S) & Natural Logarithm - ln of Total Sales \\
\hline Earning Volatility (EV) & Absolute Value at the Level of First Difference of ln f Total Sales \\
\hline Profitability (P) & Earnings before Interest and Tax / Total Assets Ratio \\
\hline Growth Opportunity (GO) & Average of First Difference of Natural Logarithm of Total Sales \\
\hline Asset Tangibility (AT) & Tangible Fixed Assets / Total Assets Ratio \\
\hline Dividend Payout (DP) & Cash Dividend Paid / Profit after Tax Ratio \\
\hline Tax Shield (TS) & Depreciation, Amortization and Depletion / Total Assets Ratio \\
\hline Total Leverage (TL) & Total Liabilities / Total Assets Ratio \\
\hline
\end{tabular}

\begin{tabular}{|l|l|}
\hline Long Term Leverage (LTL) & Noncurrent Liabilities/ Total Assets Ratio \\
\hline Short Term Leverage (STL) & Current Liabilities / Total Assets Ratio \\
\hline Gross Domestic Product (GDP) & GDP Current \\
\hline Imports (M) & Percentage of GDP \\
\hline Exports (X) & Percentage of GDP \\
\hline Inflation Rate (INF) & Consumer Price Index (CPI) at Annual Percentage \\
\hline Market Capitalization (MC) & Value of Outstanding Shares in Stock multiplied by the Price of Shares \\
\hline Exchange Rate (ER) & Average Value of PKR/US\$ \\
\hline Interest Rate (IR) & Nominal Interest Rate \\
\hline
\end{tabular}

Table-III indicates that $\mathrm{S}$ has significant positive correlation with $\mathrm{P}, \mathrm{GO}$, TL and STC which indicates that firm size increase profitability and growth as well. Moreover, Leverage has a sound relationship with the firm size. It's due to financing assets to managing the size of firm in long run. However, firm size has negative significant association with asset tangibility. The earnings volatility has significant positive association with DP at $\mathrm{p}<0.01$ which reflects that high earnings may cause to provide high dividend profitability which is negatively associated with assets tangibility and long term leverage. However, positively associated significantly with short term leverage. Asset tangibility has significant positive 
relation with long term leverage and significantly negative association with short term leverage. The profitability of firm has significant positive correlation with exchange rate, LTL has negative correlation with ER and M. Market capitalization has negative significant correlation with GDP and INF at $\mathrm{p}<.01$. However, positive correlation with exports significantly at $\mathrm{p}<0.01$.

Table-III

Coefficients of Correlation of Firms Specific Variables, Macroeconomic Conditions and Capital Structure

\begin{tabular}{|c|c|c|c|c|c|c|c|c|c|c|c|c|c|c|c|c|c|}
\hline ? & $S$ & EV & $\mathrm{P}$ & GO & $\mathrm{AT}$ & $\mathrm{DP}$ & TS & $\mathrm{TL}$ & LTL & STL & GDP & $\mathrm{M}$ & $\mathrm{E}$ & INF & $\mathrm{MC}$ & ER & IR \\
\hline $\mathrm{S}$ & 1.00 & & & & & & & & & & & & & & & & \\
\hline EV & 0.06 & 1.00 & & & & & & & & & & & & & & & \\
\hline $\mathrm{P}$ & $.34 * *$ & 0.12 & 1.00 & & & & & & & & & & & & & & \\
\hline GO & $.23^{*}$ & 0.02 & 0.07 & 1.00 & & & & & & & & & & & & & \\
\hline AT & $-.28^{*}$ & -0.14 & $\begin{array}{r}- \\
.53^{* *} \\
\end{array}$ & 0.05 & 1.00 & & & & & & & & & & & & \\
\hline DP & -0.07 & $.49^{* *}$ & 0.11 & 0.07 & -0.02 & 1.00 & & & & & & & & & & & \\
\hline TS & 0.09 & 0.02 & 0.05 & 0.06 & 0.06 & 0.02 & 1.00 & & & & & & & & & & \\
\hline TL & $.64 * *$ & 0.11 & -0.03 & $\begin{array}{c}- \\
0.01\end{array}$ & -0.15 & $\begin{array}{c}- \\
0.01\end{array}$ & 0.13 & 1.00 & & & & & & & & & \\
\hline LTL & 0.03 & -0.11 & $\begin{array}{r}- \\
.39 * * \\
\end{array}$ & 0.03 & $.75 * *$ & $\begin{array}{c}- \\
0.01 \\
\end{array}$ & 0.10 & $.35 * *$ & 1.00 & & & & & & & & \\
\hline STL & $.59^{* *}$ & 0.19 & $.27 *$ & $\begin{array}{c}- \\
0.03\end{array}$ & $\begin{array}{c}- \\
.73^{*} * \\
\end{array}$ & $\begin{array}{c}- \\
0.01\end{array}$ & 0.04 & $.68^{* * *}$ & $\begin{array}{c}- \\
.45^{* *} \\
\end{array}$ & 1.00 & & & & & & & \\
\hline GDP & 0.00 & -0.12 & -0.20 & $\begin{array}{c}- \\
0.12\end{array}$ & 0.07 & $\begin{array}{c}- \\
0.20\end{array}$ & 0.20 & 0.05 & 0.08 & $\begin{array}{c}- \\
0.02\end{array}$ & 1.00 & & & & & & \\
\hline $\mathrm{M}$ & -0.06 & 0.02 & 0.11 & 0.02 & -0.21 & 0.01 & $\begin{array}{c}- \\
0.02 \\
\end{array}$ & 0.00 & -0.23 & 0.18 & $\begin{array}{r}- \\
.41^{* *}\end{array}$ & 1.00 & & & & & \\
\hline $\mathrm{E}$ & 0.07 & 0.16 & 0.11 & 0.14 & -0.01 & 0.16 & $\begin{array}{c}- \\
0.15 \\
\end{array}$ & -0.08 & -0.06 & $\begin{array}{c}- \\
0.03\end{array}$ & $-.29^{*}$ & $\begin{array}{c}- \\
.37 * *\end{array}$ & 1.00 & & & & \\
\hline INF & 0.05 & -0.05 & -0.09 & 0.16 & -0.03 & 0.09 & $\begin{array}{c}- \\
0.10\end{array}$ & 0.09 & 0.02 & 0.08 & -0.19 & $.55^{* *}$ & $\begin{array}{c}- \\
.39 * *\end{array}$ & 1.00 & & & \\
\hline $\mathrm{MC}$ & -0.07 & 0.11 & 0.22 & $\begin{array}{c} \\
0.10\end{array}$ & -0.07 & $\begin{array}{c} \\
0.03 \\
\end{array}$ & 0.03 & -0.12 & -0.13 & $\begin{array}{c}- \\
0.02 \\
\end{array}$ & $-.28^{*}$ & -0.14 & $.47 * *$ & $\begin{array}{r}- \\
.83^{* *}\end{array}$ & 1.00 & & \\
\hline ER & -0.03 & 0.16 & $.25^{*}$ & 0.06 & -0.19 & 0.13 & $\begin{array}{c}- \\
0.13 \\
\end{array}$ & -0.09 & $-.23^{*}$ & 0.10 & $\begin{array}{c}- \\
.82^{* *} \\
\end{array}$ & $.58 * *$ & $.41 * *$ & -0.04 & $.54 * *$ & 1.00 & \\
\hline IR & -0.08 & 0.02 & 0.15 & $\begin{array}{c}- \\
0.11\end{array}$ & -0.07 & $\begin{array}{c}- \\
0.13 \\
\end{array}$ & 0.13 & -0.09 & -0.14 & 0.02 & 0.08 & -0.08 & 0.13 & $\begin{array}{r}- \\
.64^{* *} \\
\end{array}$ & $.77 * *$ & 0.20 & 1.00 \\
\hline
\end{tabular}

Table-IV reports micro characteristics of firms and capital structure by SUR model. It shows that $\mathrm{S}$ is significant and positively determines TL, LTL and STL at $\mathrm{p}<.01$ respectively. $\mathrm{P}$ is negative and significant determinant of TL and LTL at $\mathrm{p}<.010$ correspondingly. This can be explained by the fact that when profitability is low, firms resort to sourcing for more funds to run their activities.

GO and all the three leverages were negatively targeted with the values at $\mathrm{p}<0.01$ respectively because firms which have less growth opportunities have less resources so they have to go for debts. The coefficients of AT were 0.474 and -0.55 for and STL, respectively indicating that firms which have more tangible assets have the ability to raise more long term level debts but have to reduce short term level of borrowings. DP did not determine the leverage which indicates that it has no effect on capital structure which supports the Modigliani and Miller (1958)'s irrelevance theory. The overall fitness of the model was appropriate because the value of $\mathrm{Chi}^{2}>60$ and significant. 
Table IV

SUR Model of Firms Specific Variables and Capital Structure

\begin{tabular}{|l|c|c|c|}
\hline Dependent Variable & TL & LTL & STL \\
\hline S & $0.070^{* * *}$ & $0.022^{* * *}$ & $0.048^{* * *}$ \\
\hline EV & 0.004 & -0.002 & 0.006 \\
\hline P & $-3.971^{*}$ & $-3.200^{*}$ & -0.771 \\
\hline GO & $-0.075^{*}$ & -0.028 & -0.047 \\
\hline AT & -0.082 & $0.474 * * *$ & $-0.555^{* * *}$ \\
\hline DP & 0.000 & 0.000 & 0.000 \\
\hline TS & 0.062 & 0.022 & 0.040 \\
\hline Constant & $-0.630^{* * *}$ & $-0.480^{* * *}$ & -0.150 \\
\hline Chi $^{2}$ & $92.98^{* * *}$ & $142.48^{* * *}$ & $246.77 * * *$ \\
\hline
\end{tabular}

**** Significant at $\mathbf{p}<.01$

$* *$ Significant at $\mathbf{p}<.05$

* Significant at $\mathbf{p}<.10$

Table-V reported micro characteristics of firms, industry and capital structure during the study period in Pakistan. S has no significant impact on any type of leverage with the inclusion of dummy variables of industry. EV did not significantly determine the target ratios of leverage. $\mathrm{P}$ has significant and negative impact on LTL because when profitability decreases then the firms have to borrow for long time period for their survival. No significant relationship was found between GO, TS, DP and ratios of leverage. AT has positive and significant impact on LTL with the value of 0.450 and has significant negative impact on STL with coefficient of -0.454 . From all the sectors PB has no significant impact on capital structure. T and EM both have significant impact on TL, LTL and STL with the values of $-0.091,-0.069$ and 0.386 , respectively for $\mathrm{T}$ and $0.011,-0.073$ and 0.438 respectively for $\mathrm{EM}$. F and FE sectors both have mix significantly positive and negative impact on LTL and STL only with the values of -0.108 and 0.536 , respectively for $\mathrm{F}$ and -0.056 and 0.412 , respectively for FE.

CP, ONMM, MVAP and OS sectors have significantly positive and negative impact on only TL and LTL with the values of -0.178 and -0.014 for CP sector, -0.055 and -0.095 for ONMM sector and 0.002 and 0.246 for MVAP respectively. ICT sector has only impact on STL with the value of 0.412 . CRP has significant negatively and positively impact on TL and STL with the values of -0.432 and 0.437 , respectively. The overall model was fit because the value of Chi2 $>60$ and significant.

\section{Table V}

\section{SUR Model of Firms Specific Variables, Industry and Capital Structure}

\begin{tabular}{|l|c|c|c|}
\hline Dependent Variable & T L & LTL & STL \\
\hline S & 0.011 & -0.005 & 0.017 \\
\hline EV & 0.002 & 0.000 & 0.002 \\
\hline P & -2.512 & $-3.391^{* *}$ & 0.879 \\
\hline GO & -0.009 & -0.004 & -0.005 \\
\hline AT & -0.003 & $0.450^{* * *}$ & $-0.454^{* * *}$ \\
\hline DP & 0.000 & 0.000 & 0.000 \\
\hline TS & -0.017 & 0.031 & $-0.048^{*}$ \\
\hline T & $-0.091^{* *}$ & $-0.069^{* *}$ & $0.386^{*}$ \\
\hline F & -0.132 & $-0.108^{*}$ & $0.536^{*}$ \\
\hline CP & $-0.178^{*}$ & $-0.014^{* *}$ & 0.335 \\
\hline OM & $-0.181^{* * *}$ & -0.108 & $0.388^{*}$ \\
\hline ONMM & $-0.055^{* * *}$ & $-0.095^{* *}$ & 0.328 \\
\hline MVAP & $-0.035^{* * *}$ & $-0.075^{* * *}$ & 0.305 \\
\hline FE & -0.074 & $-0.056^{*}$ & $0.412^{*}$ \\
\hline ICT & -0.253 & 0.036 & $0.412^{*}$ \\
\hline
\end{tabular}




\begin{tabular}{|l|c|c|c|}
\hline CRP & $-0.432^{* * *}$ & -0.100 & $0.437^{*}$ \\
\hline PB & 0.537 & -0.046 & 0.205 \\
\hline EM & $0.011^{* * *}$ & $-0.073^{*}$ & $0.438^{*}$ \\
\hline OS & $0.002^{*}$ & $-0.246^{* * *}$ & 0.225 \\
\hline Constant & $-2.512^{*}$ & 0.125 & -1.1935 \\
\hline Chi $^{2}$ & $701.35^{* * *}$ & $475.45^{* * *}$ & 12499.81 \\
\hline Observations & 72 & 72 & 72 \\
\hline
\end{tabular}

**** Significant at $\mathbf{p}<.01$

** Significant at $\mathbf{p}<.05$

* Significant at $\mathrm{p}<.10$

Table-VI reports the results of microeconomic characteristics of firms, industry, macroeconomic conditions and capital structure. From all micro characteristics of firms, $\mathrm{P}$ has negatively significant impact on LTL and STL with the values of -0.348 and -0.258 , respectively. It indicate that the firms which were more profitable prefer less leverage AT have negative relation with STL with the value of 0.219. It has negatively significant relation with STL with the value of -0.053 .

From all sectors T, F, CP, ONMM significantly and positively determined the target debt ratios with the values of $0.002,0.02$ and 0.060 for $\mathrm{T}$ sector, $0.005,0.007$ and 0.059 for $\mathrm{F}$ sector, $0.011,0.036$ and 0.062 for $\mathrm{CP}, 0.002,0.017$ and 0.230 for ONMM, respectively. OM sector was negatively and significantly related with STL but positively associated with TL by the values of -0.056 and 0.034 , respectively. MVAP sector was preferred more STL as compared to LTL with the value of 0.024 .

FE sector has positively preferred STL but negatively to total and long term debt with the values of 0.030 , -0.033 and -0.007 respectively. ICT sector has positive relation with LTL and STL but negative to TL with the values of $0.144,0.186$ and -0.001 , respectively. PB sector was preferred STL but EM sector preferred LTL by 0.106 and 0.331 , respectively. At the end OS sector was targeted to TL by 0.280 . From macroeconomic conditions $\mathrm{M}$ and $\mathrm{X}$ both were determined by STL by the coefficients values of 0.178 and 0.184 , respectively.

INF was positively and significantly determined by STL. It indicates that firms prefer more short term debt under inflationary situations. MC has negative, ER and IR have positive relation with STL with the coefficients values of $-0.008,0.278$ and 0.454 , respectively. The results obtained showed that macroeconomic factors also have impact on capital structure decisions of firms. Overall model was fit because $\mathrm{Chi}^{2}$ value was greater than 60 .

Table VI

SUR Model of Firms Specific Variables, Industry, Macroeconomic Conditions and Capital Structure

\begin{tabular}{|l|c|c|c|}
\hline Dependent Variable & TL & LTL & STL \\
\hline S & 0.010 & -0.009 & 0.019 \\
\hline EV & 0.002 & -0.001 & 0.003 \\
\hline P & $-0.348^{*}$ & -0.090 & $-0.258^{*}$ \\
\hline GO & -0.004 & 0.013 & -0.017 \\
\hline AT & -0.065 & 0.154 & $-0.219^{*}$ \\
\hline DP & 0.000 & 0.000 & 0.021 \\
\hline TS & -0.025 & 0.028 & $-0.053^{* *}$ \\
\hline T & $0.002^{* * *}$ & $0.002^{*}$ & $0.060^{* * *}$ \\
\hline F & $0.005^{* * *}$ & $0.007^{* *}$ & $0.059^{* * *}$ \\
\hline CP & $0.011^{* *}$ & $0.036^{* * *}$ & $0.062^{*}$ \\
\hline OM & $0.034^{* * *}$ & 0.009 & $-0.056^{* * *}$ \\
\hline
\end{tabular}




\begin{tabular}{|l|c|c|c|}
\hline ONMM & $0.002^{* *}$ & $0.017^{* * *}$ & $0.230^{* *}$ \\
\hline MVAP & 0.000 & 0.004 & $0.024^{* *}$ \\
\hline FE & $-0.033^{* *}$ & $-0.007^{* *}$ & $0.030^{* *}$ \\
\hline ICT & $-0.001^{* * *}$ & $0.144^{* * *}$ & $0.186^{* * *}$ \\
\hline CRP & 0.330 & 0.147 & 0.286 \\
\hline PB & $0.434^{*}$ & 0.225 & $0.106^{* * *}$ \\
\hline EM & $0.331^{* *}$ & $0.080^{* * *}$ & 0.200 \\
\hline OS & $0.280^{* * *}$ & 0.174 & 0.084 \\
\hline GDP & 0.258 & 0.026 & $0.178^{*}$ \\
\hline M & 0.204 & 0.181 & $0.184^{*}$ \\
\hline X & 0.365 & 0.257 & $0.187^{*}$ \\
\hline INF & $0.443^{* * *}$ & 0.050 & $0.278^{* *}$ \\
\hline MC & 0.328 & 0.183 & $-0.008^{*}$ \\
\hline ER & 0.175 & 0.085 & $0.278^{*}$ \\
\hline IR & 0.363 & 0.356 & $0.453^{*}$ \\
\hline Constant & $-3.645^{* *}$ & 0.231 & $-2.523^{* *}$ \\
\hline Chi ${ }^{2}$ & $840.5^{* * *}$ & $544.6^{* * *}$ & $1730.79^{* * *}$ \\
\hline
\end{tabular}

*** Significant at $\mathbf{p}<.01$

** Significant at $\mathbf{p}<.05$

* Significant at $\mathbf{p}<.10$

\section{Conclusion}

Results indicate that targeted debt ratios have variation during sample period and TL had major part of the short term debt. AT, P, S, EV, GO, TS, and DP had been changing over time in accordance with LTL and a light behavior was related with TL. It was also found that firms prefer less debt which have more profit and vice versa. Mayers (2001) explored that the increase in debt lead to reduction of tax burden supports to tradeoff theory by Kraus Litzenberger (1973).

Meckling, 1976 and Ross, 1977 described tradeoff- theory regarding that more asset tangibility more capital structure. It is supported by the pecking order theory of Myers and Majluf, 1984. DP was not determined by the leverage, indicating that it has no effect on capital structure and thus supports the Modigliani and Miller (1958)'s irrelevance theory. The results depicted a strong and significant association of TL with S LTL was significantly related with P and AT STL was significantly associated with S, P and AT. The positive direction of the association between STL and S indicated that S increases, STL also increases and same was the case with P. The negative profitability is supported to more debt as prescribed in pecking order theory. The positive tax shield is also version of trade off theory. The size (SZ) is positive with debt vs. equity and consistent with Rajan and Zingales, 1995. The less information asymmetry of large firms supports that new equity will never be undervalue, So that large size of firms can have potential to issue more financing. The growth is positive significant with capital structure. It supports to utilize more debt by Shah and Hijazi, 2005. Krause and Litzenberger (1973) indicated that the negative signs contradict with the trade off theory.

These associations were according to the trend of debt borrowing in Pakistan. The short term debt has major part in Pakistani companies leverage. In short, overall results of firms related variables and capital structure play a significant role. On the other side, effect of industry also matters in determining capital structure choices. From all sectors, PB has no significant impact on capital structure. T and EM both have significant impact on TL, LTL and STL. F and FE sectors both have mixed and significantly positive and negative impact on LTL and STL. OM sector was negatively and significantly related with STL but positively associated with TL.

MVAP sector was preferred more STL as compared to LTL. ICT sector has positive relation with LTL and STL but negative association with TL. At the end, OS sector was targeted to TL. This variation due to industry effect is an evidence that the industry has significant effect on capital structure. From the 
perspective of macroeconomic conditions, both $\mathrm{M}$ and $\mathrm{X}$ were determined by STL. INF was positively and significantly determined by STL, indicating that the firms preferred more short term debt under inflationary situations. MC has negative relation, the increase or decrease in market value change in capital structure where inconsistent with Modigliani and Miller 1958 of prior findings where the market value is irrelevant to capital structure. Modigliani and Miller 1963 supports negative association to firm value has an increase in cost of equity with increase in debt.

The ER and IR have positive relation with target short term debt. The high exchange rate (ER) will create the decrease in cash to high interest. The exchange rate (ER) negative means the reduction in capital structure. There is need of minimum cost of capital to less debt. The negative interest rate (IR) is meant to reduction in capital choice due to high agency cost of agency theory. It is not favorable the tax shield benefit due to its negative relation.

The results reveal that macroeconomic factors also have impact on capital structure choices. Overall, the study concludes that debt ratios may vary due to firms' related variables, industry and macroeconomic conditions in Pakistani perspective. This study will identify the guidelines for the potential investors to overcome the crucial issues related to macroeconomic variables prevailing in the market at national or international level. The assets, size, growth and risk are used to create a balance of agency costs and debt benefits. The short-term debt as compared to internal source of financing adds value to grow at early level of development. The long-term financing also has more benefits due to the tax shield. The debt is cheapest rather than equity finance due to non transfer of ownership and fixed liability. The inherent risk creates asymmetry of information. The profitability and liquidity would tend to manage asymmetry of information due to potential of maximum collateral and repayment fixed liability of debt. The macroeconomic factors also have vital role in operations of firms and their financial freedom. The macroeconomic factors i.e. inflation tends to increase financial distress and costs. The financial distress and costs are significant in financial market development. The financial development is equally important in financial structure decisions and their maturities. The favorable role of macroeconomic policy provides assistance to reduce agency behavior, asymmetry of information and risk. The policies and decisions can have best implications to improve and facilitate business environment of firm through wide access of capital. The policy of business governance structure and legal framework encouraged creditors, firm business affairs and growth environment. The growth environment is a key to investment and future growth to the financial market. This study will provide a way to the managers, investors, policy makers for enhancing the activities. Furthermore the policy makers, investors, noise traders and managers can predict the capital structure decisions by applying the macroeconomic strategies in Pakistani economy. This empirical study will also show impact of endeavors of potential players with a view to conduct further research in future in perspective of developing nations.

\section{References}

Afza, T., Hussain, A., (2011). Determinants of Capital Structure: A Case Study of Automobile Sector of Pakistan, Interdisciplinary Journal of Contemporary research in business. , 2 (10):219-230

Adizes, I., (1979). Organizational passages: Diagnosing and treating lifecycle problems of organizations, Organizational Dynamics, 8(1): 3-25.

Antoniou A., Guney Y., and Paudyal, K., (2008). The determinants of capital structure: Capital marketoriented versus bank-oriented institutions, Journal of Financial and Quantitative Analysis, 43 (1):59-92.

Baker, M., and Wurgler, J., (2002). Market timing and capital structure”, The Journal of Finance, 57(1):132.

Banjeree, S., Heshmati, A., and Whilborg, C., (2004). The dynamics of capital structure, Research in 
Banking and Finance, 4 (1):275-97.

Barclay, J,M., Smith, W,C. and Watts, R., (1995). The Determinants of Corporate Leverage and

Dividends Policies," Journal of Applied Corporate Finance, 7(4): 4-19.

Bender, R and Ward, K.,(1993). Corporate Financial Strategy", Oxford ButterworthHeinemann.

Coase, R. H., (1937). The Nature of the Firm. Economica, New Series, 4(16): 386-405.

Durand, D., (1952). Cost of debt and equity funds for business: Trends and problems of measurement, Conference Research Business Finance, New York: National Bureau of Economic Research, 215-247.

Eldomiaty, T., (2007). Determinants of corporate capital structure: Evidence from an emerging economy", International Journal of Commerce \& Management, 17 (1/2):25-43.

Frank, M. Z., \& Goyal, V. K., (2004). The effect of market conditions on capital structure adjustment. Finance Research Letters, 1(1), 47-55.

Frielinghaus, A., Mostret B., and Firer, C., (2005). Capital structure and firms life stage, South African Journal of Business Management, 36(4):9-18.

Graham, J. R. and Harvey, C. R., (2001). The theory and practice of corporate finance: evidence from the field, Journal of Financial Economics, 60 (2/3):187-243.

Gujarati, D., (2003). Basic Econometrics, McGraw-Hill, New York, NY.

Harkbarth, D., Miao, J., and Morellec, E., (2006). Capital structure, credit risk and macroeconomic conditions", Journal Financial Economics, 82 (3):519-50.

Harris, M., and Raviv, A., (1990). Capital Structure and the Informational Role of Debt, Journal of Finance, 45(2):321-349.

Hatfield, B. G., Cheng, T.W. L., and Davidson, N .W., (1994). The Determination of Optimal Capital Structure: The Effect of Firm and Industry Debt Ratios on Market Value, Journal of Finance \& Strategic Decision, 7:1-14.

Henderson, B., Jegadeesh, N., and Weisbach, M. S., (2006). World markets for raising new capital, Journal of Financial Economics, 82 (1):63-101.

Hsiao, C., 1985, Benefits and limitations of panel data", Econometric Reviews, 4 (1):121-174.

Jensen, M. C. and. Meckling, W. H., (1976). Theory of the firm: Managerial behavior, agency costs and ownership structure, Journal of Financial Economics. 3:305-360.

Kim, H and Berger, D, P., (2008). A Comparison of Capital Structure Determinants: The United States and the Republic of Korea Multinational Business Review, 16(1):79-100

Kim, C., (1978). A mean-variance theory of optimal capital structure and corporate debt capacity, Journal of Finance, 33 (1):45-63.

Kochhar, R., (1996). explaining firm capital structure: The role of agency theory vs. transaction cost economics, Journal of Strategic Management, 17:713-728.

Kraus, A. and Litzenberger, R., 1973, A state-preference model of optimal financial leverage, Journal of Finance, 28 (4):911-922.

Levine, R., (2004). Finance and growth: theory and evidence, NBER Working Paper No. 10766, National Bureau of Economic Research, Cambridge, MA.

Miller, M. H., (1977). Debt and taxes, Journal of Finance, 32 (2):261-275.

Modigliani, F. and Miller, M. H., (1963). Corporate income taxes and the cost of capital: A correction, American Economic Review, 53 (3):433-443.

Modigliani, F. and Miller, M. H., (1958). The cost of capital, corporation finance and the theory of investment, American Economic Review, 48 (3):261-297.

Myers, S., (2001). Capital structure, The Journal of Economic Perspectives, 15 (2):81-102.

Myers, S., (1984). The capital structure puzzle, Journal of Finance, 39 (3):575-592.

Myers, S. C. and Majluf, N., (1984). Corporate Financing and Investment Decisions when Firms have information that Investors do not have, Journal of Financial Economics, 13, 187-221. 
Parson, C. A. and Titman, S., (2007). Capital structure and corporate strategy, in B.E. Eckbo (Ed.), Handbook of Empirical Corporate Finance, Elsevier B.V., Amsterdam.

Prasad, S. J., Green, C. J., and Murinde, V., (2001). Corporate financial structures in developing economies: Evidence from a comparative analysis of Thai and Malay corporations, Finance \& Development Research Programme Working Paper No 35.

Rajan, Raghuram G. and Zingales, Luigi, (1995). What do we know about capital structure? Some evidence from international data, Journal of Finance, 50, 1421-1460.

Ross, S. A., (1977). The determination of financial structure: The incentive-signaling approach, Bell Journal Economics, 8, 23-40.

Shah, Atta, and Hijazi S., (2005). The Determinants of Capital Structure in Pakistani Listed NonFinancial Firms", presented at $20^{\text {th }}$ AGM \& Conference of Pak Society of Development Economics

Swanson, Z., Srinidhi, B., and Seetharaman, A., (2003). The capital structure paradigm: Evolution of debt/equity choices, London: Praeger.

Titman, S. and Wessels, R. (1988). The determinants of capital structure choice, Journal of Finance, 43 (1) 1-19.

Toy, N., A. Stonehill, L. Remmers, R. W, and Beekhuisen,T.,(1974). A comparative international study of growth, profitability, and risk as determinants of corporate debt ratios in the manufacturing sector, Journal of Financial and Quantitative Analysis, 9,75-886.

Tse, B. C. and Jia, Y. J., (2007),.The impacts of corporate ownership structure on the incentive of using capital structure to signal, Studies in Economics and Finance, 24: 2.

Williamson, O., (1988). Corporate finance and corporate governance, Journal of Finance, 43:567-591.

Zweibel, J., (1996) Dynamic capital structure under managerial entrenchment, American Economic Review, 86 (5) 1197-215. 